\title{
Aminopeptidases in the Acidic Fraction of the Yeast Autolysate
}

\author{
Tasaburo Masuda, Rikimaru Hayashi ${ }^{\dagger}$ and Tadao $\mathrm{HATA}^{\dagger}$ \\ The Research Institute for Food Science, Kyoto University, Uji, Kyoto 611
}

Received August 28, 1974

\begin{abstract}
Two aminopeptidases, I and II, were found in the acidic fraction of the yeast autolysate, adsorbed on DEAE-cellose and DEAE-Sephadex A-50. Aminopeptidase I was purified as a single protein with a molecular weight of 200,000 . The enzyme required $\mathrm{Zn}$ for its activity and hydrolyzed dipeptides, and a polypeptide (glucagon). It also hydrolyzed amides, naphthylamides and the $p$-nitroanilide of amino acids. The enzyme was strongly inhibited by sulfhydryl reagents. Aminopeptidase II seemed also to be a metal enzyme with a molecular weight of 34,000 . The enzyme hydrolyzed the dipeptide and tetrapeptide but not leucine-p-nitroanilide.
\end{abstract}

To determine the proteolytic system of yeast, Hata, Hayashi and their associates have purified two endopeptidases (proteinases $\mathrm{A}$ and B), ${ }^{1)}$ a CPase (CPase $\mathrm{Y}$ ) ${ }^{2)}$ and the inactive forms of proteinase $\mathrm{B}^{3)}$ and CPase $\mathrm{Y}^{4}{ }^{4}$ During these studies, they found aminopeptidases in a fraction of the yeast autolysate. ${ }^{5)}$ APases in yeast were first described by Grassmann et al..$^{6 \sim 8\rangle}$ Thereafter, Johnson ${ }^{9 /}$ purified another APase (aminopolypeptidase) from Saccharomyces cerevisiae as a single protein, the molecular weight of which was 670,000 . However, the APases which we found seemed to differ from the known ones.

In an extension of the studies on the proteolytic enzymes of yeast, the present report describes the purification and properties of the new APases. Purification of these APases started from step 6 in the purification of CPase $Y^{2,5)}$

\section{MATERIALS}

Compressed bakers' yeast was obtained from the Oriental Yeast Company; Leu* $-\beta$ NA from the Protein Research Foundation; DFP, S-Bzl-Cys-OMe and

\footnotetext{
Abbreviations used: APase, aminopeptidase; Bzl, benzyl; $\beta$ NA, $\beta$-naphthylamide; CPase, carboxypeptidase; DFP, diisopropylfluorophosphate; $\mathrm{OMe}$, methylester; PCMB; $p$-chloromercuribenzoate; $p \mathrm{NA}, p$ nitroanilide;

$t$ To whom correspondence should be addressed.

4. * Unless otherwise specified, all amino acids had the $\mathrm{L}$ configuration, except for glycine.
}

glucagon from Sigma; $\gamma$-globulin from the Nutritional Biochemical Corporation; glutamate dehydrogenase from Boehringer; and Leu- $p$ NA from Nakarai Chemicals. Phe-Phe, Leu-Phe, Leu-Leu, Leu-Gly, Phe-Gly, Ala-Gly, Val-Gly, and D-Phe-Leu were synthesized. ${ }^{10)}$ Ala-Gly-Val and Gly-Leu-Phe-Gly were kindly supplied by Dr. Sano of the Department of Public Health of Kyoto University. Ile-Phe was synthesized by conventional methods.

\section{EXPERIMENTAL METHODS}

Enzyme assays. Three methods were used to determine the activity of APase: 1) Activity against Leu- $p$ NA was measured by the increase in absorbance at $405 \mathrm{~nm}$ using a spectrophotometer (Hitachi model 124). The assay was performed in a $1 \mathrm{~cm}$ cuvette at $25^{\circ} \mathrm{C}$ by adding $50 \mu \mathrm{l}$ of enzyme solution to $1.95 \mathrm{ml}$ of $1 \mathrm{~mm}$ Leu- $p \mathrm{NA}$ in $50 \mathrm{~mm}$ Tris- $\mathrm{HCl}, \mathrm{pH}$ 7.6. The increase in absorbance was recorded for about $5 \mathrm{~min}$. The extinction coefficient of $p$-nitroaniline was taken as $9.9 \times 10^{3} \mathrm{M}^{-1} \cdot \mathrm{cm}^{-1}$. 2) Activity against dipeptide was measured by the decrease in absorbance at $224 \mathrm{~nm}$ as in the first method. The concentration of substrate was $1 \mathrm{~mm}$ in $50 \mathrm{~mm}$ Tris- $\mathrm{HCl}$, pH 7.6. The molar extinction of the peptide bond in each substrate at $224 \mathrm{~nm}$ was calculated from the difference in molar extinctions between the substrate and the mixture of constituent amino acids. 3) Activity against Leu$\beta N A$ was measured according to the method of Wüst. ${ }^{11)}$ The enzyme solution $(10 \mu \mathrm{l})$ was added to $0.99 \mathrm{ml}$ of $0.02 \%$ Leu- $\beta \mathrm{NA}$ in $50 \mathrm{~mm}$ Tris- $\mathrm{HCl}, \mathrm{pH}$ 8.0 , then the reaction mixture was incubated at $25^{\circ} \mathrm{C}$ for $30 \mathrm{~min}$. The reaction was terminated by the addition of $0.25 \mathrm{ml}$ of $40 \% \mathrm{HClO}_{4}$. Diazotization of the liberated $\beta$-naphthylamine and color development were performed using the procedure described by Wüst. ${ }^{11}$ One unit of enzyme activity is defined as the amount 
of enzyme catalyzing the hydrolysis of $1 \mu$ mole of substrate per minute.

Determination of molecular weight. The molecular weight was estimated by the gel filtration procedure using Sephadex G-200 (column size, $1.5 \times 90 \mathrm{~cm}$ ). The buffer used for elution was $10 \mathrm{~mm}$ sodium phosphate, $\mathrm{pH} 7.0$, containing $0.1 \mathrm{M} \mathrm{NaCl}$. The flow rate was $10 \mathrm{ml}$ per hour. Bovine serum albumin (M.W. 67,000), $\gamma$-globulin (M.W. 156,000) and glutamate dehydrogenase (M.W. 320,000) were used as the standard proteins.

Electrophoresis on cellulose acetate membrane. Electrophoresis on a cellulose acetate membrane (Schleicher and Schüll GMBH) was carried out with $50 \mathrm{~mm}$ sodium phosphate buffer, $\mathrm{pH} 7$ for $45 \mathrm{~min}$ at $1 \mathrm{~mA}$ per $\mathrm{cm}$ and at room temperature.

Digestion of glucagon by APase. Three $\mu \mathrm{g}$ of aminopeptidase was added to about $1 \mathrm{mg}$ of glucagon dissolved in $1 \mathrm{ml}$ of $50 \mathrm{~mm}$ Tris- $\mathrm{HCl}$ buffer, $\mathrm{pH} \mathrm{7.6.}$ The mixture was incubated at $37^{\circ} \mathrm{C}$. Aliquots $(20 \mu \mathrm{l})$ were withdrawn at 15 min-intervals, and immediately immersed in a boiling water bath for a few minutes to terminate the reaction. After the buffer had been removed in a desiccator under a vacuum, the samples were dissolved in $\mathrm{pH} 2.2$ buffer and placed in an automatic amino acid analyzer (Yanagimoto LC-5S).

Determination of protein concentration. Protein concentrations were measured by the method of Lowry et al. ${ }^{111}$ and were calibrated with a standard solution of bovine serum albumin.

\section{RESULTS}

Fractionation and purification of enzymes

On the first DEAE-Sephadex chromatography, which was conducted to purify CPase $Y^{2}{ }^{2}$ APase appeared on the protein peak just before proteinase A (see Fig. 1 of References 2

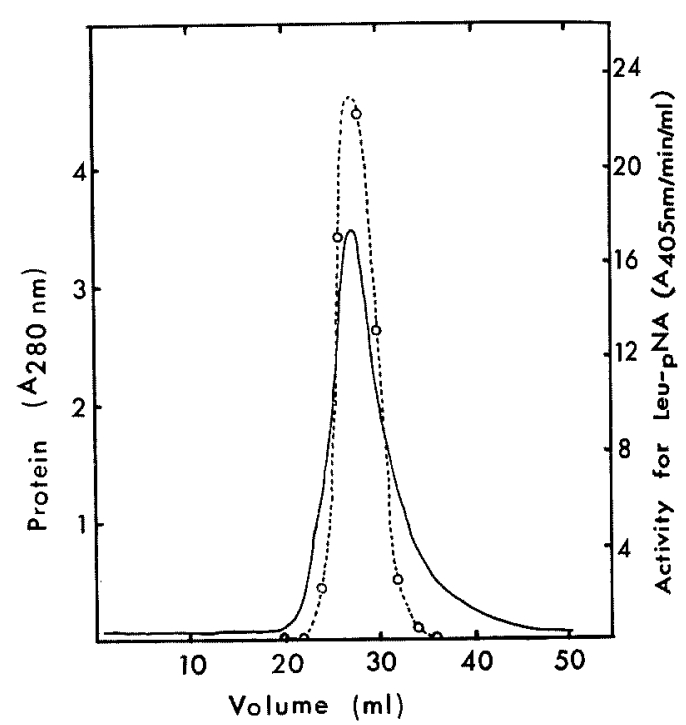

FIG. 2. Gel Filtration of APase I through Sephadex $\mathrm{G}-200$.

See the text for experimental details. __, protein; $\mathrm{O}-\mathrm{O}$, activity.

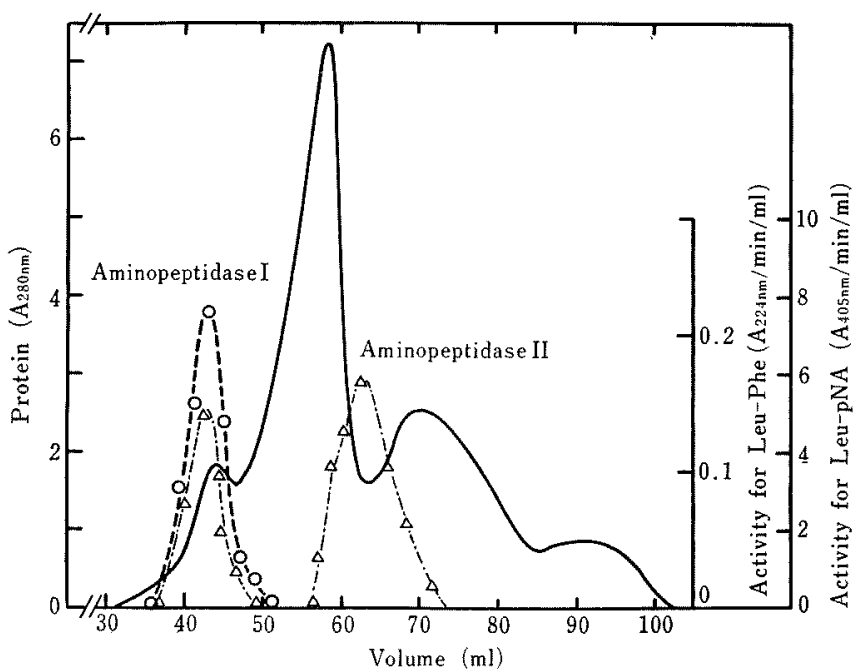

FIG. 1. Gel Filtration of the Aminopeptidase Fraction on a Column of Sephadex G-100 $(1.5 \times 90 \mathrm{~cm})$. The aminopeptidase fraction was obtained from chromatography on DEAE-Sephadex A-50 (see Fig. 1 of Reference 2). Protein (-) was eluted with $10 \mathrm{~mm}$ of sodium phosphate, pH 7.0, containing $0.1 \mathrm{M}$ of $\mathrm{NaCl}$. The flow rate was $28 \mathrm{ml}$ per hr. Aminopeptidase activity was determined toward Leu-p NA $(\triangle-\cdot-\triangle)$ and Leu-Phe $(\mathrm{O}-\mathrm{O})$. 
Table I. Purification of APase I from Baker's Yeast

\begin{tabular}{clcccc}
\hline Step & \multicolumn{1}{c}{ Procedure $^{a)}$} & Volume & Protein & $\begin{array}{c}\text { Specific } \\
\text { activity }\end{array}$ & $\begin{array}{c}\text { Yield } \\
(\%)\end{array}$ \\
\hline 1 & $\begin{array}{l}\text { Autolysis and removal of yeast } \\
\text { cell debris }\end{array}$ & $47.1 \mathrm{liters}$ & & & \\
2 & Fractionation with ammonium sulfate & $4530 \mathrm{ml}$ & $460 \mathrm{~g}$ & $7 \times 10^{-4}$ & 100 \\
3 & Activation treatment of CPase Y & $4650 \mathrm{ml}$ & $394 \mathrm{~g}$ & $7 \times 10^{-4}$ & 84.8 \\
7 & Chromatography on DEAE-cellulose & $3600 \mathrm{ml}$ & $43 \mathrm{~g}$ & $3 \times 10^{-3}$ & 40.3 \\
5 & Chromatography on DEAE-Sephadex & $360 \mathrm{ml}$ & $613 \mathrm{mg}$ & $9 \times 10^{-2}$ & 17.1 \\
6 & A-50 & $49.5 \mathrm{ml}$ & $28 \mathrm{mg}$ & 1.62 & 14.1 \\
7 & Gel filtration on Sephadex G-100 & $9.5 \mathrm{ml}$ & $14 \mathrm{mg}$ & 2.41 & 10.4 \\
\hline
\end{tabular}

a) See reference 2 for the details of steps $1 \sim 5$.

b) Micromoles of Leu- $p$ NA hydrolyzed per min per mg of protein.

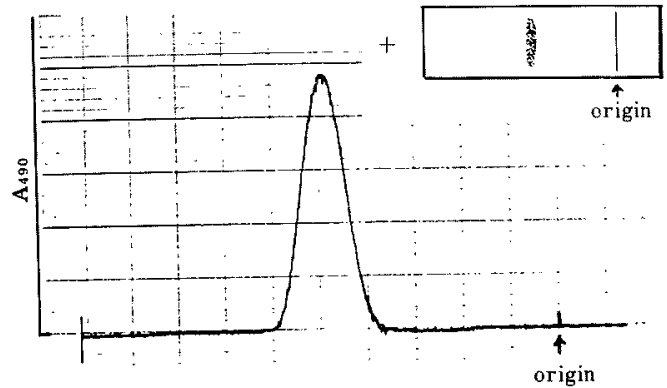

FIG. 3. Electrophoresis of APase I on a Cellulose Acetate Membrane.

The lower figure shows the tracing by a densitometer.

and 5). The active fractions were collected and concentrated by dialysis against a saturated solution of ammonium sulfate.

The precipitate was dissolved in a minimum volume of $10 \mathrm{~mm}$ sodium phosphate buffer, pH 7.0, containing $0.1 \mathrm{M} \mathrm{NaCl}$ and was applied to a column of Sephadex G-100 $(2.5 \times$ $150 \mathrm{~cm}$ ) equilibrated with the same buffer. Elution was performed with the same buffer at a flow rate of $28 \mathrm{ml}$ per hour. As shown in Fig. 1, two active APases fractions were obtained: the first which hydrolyzed both Leu$p$ NA and Leu-Phe was named APase I and the second which did not hydrolyzed Leu-pNA was named APase II.

Active fractions of APase I were collected and purified further by gel-filtration on a column of Sephadex G-200 $(1.5 \times 90 \mathrm{~cm})$. Elution was performed under the conditions described above. Figure 2 shows the elution

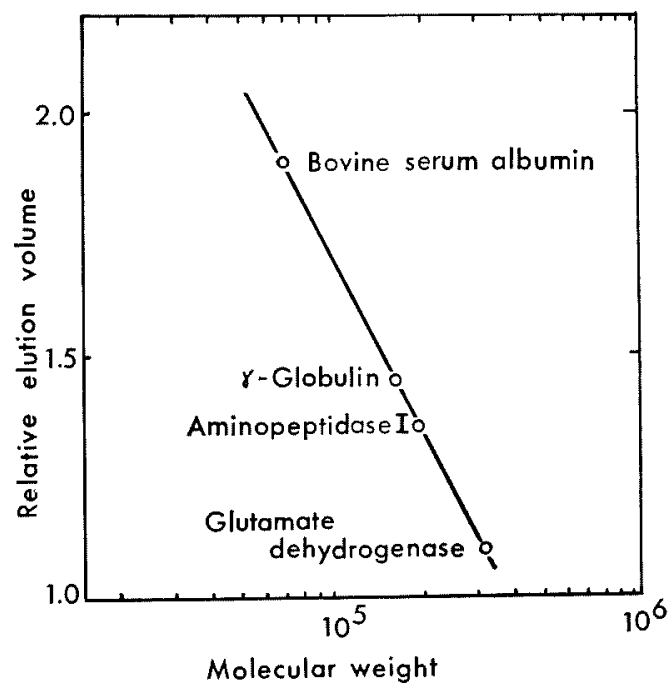

FIG. 4. Plots of Relative Elution Volume $\left(V_{\mathrm{e}} / V_{0}\right)$ on a Sephadex G-200 Column vs. Logarithms of the Molecular Weights of Proteins.

Glutamate dehydrogenase (M.W. 320,000), $\gamma$-globulin (M.W. 156,000) and bovine serum albumin (M.W. $68,000)$ were used as standard proteins. The elution volume of blue dextran was taken as 1.0.

pattern. The active fractions were collected and stored at $-20^{\circ} \mathrm{C}$. The purification procedure for APase I is summarized in Table I.

\section{Homogeneity and molecular weight}

During storage of APase I at $-20^{\circ} \mathrm{C}$, an insoluble precipitate was produced. The precipitate which had no enzymatic activity was removed by centrifugation. The supernatant solution showed a single protein band on electrophoresis, as shown in Fig. 3. This solu- 
tion, the specific activity of which was 3.5 units per mg protein against Leu- $p \mathrm{NA}$, was used as the stock solution of APase I.

Figure 4 shows the plots of the elution volumes vs. the logarithms of the molecular weight of proteins. The molecular weight of APase I was estimated as 200,000 . Similarly, the molecular weight of APase II was estimated as about 34,000 .

\section{Effects of $p H$ and temperature on activity and stability}

The effect of $\mathrm{pH}$ on the activity of APase I is shown in Fig. 5. The enzyme was most active at about $\mathrm{pH} 7.6$ for Leu- $p$ NA and LeuLeu, and at about $\mathrm{pH} 8.0$ for Leu- $\beta$ NA.

The optimum temperature for APase I was estimated at about $40^{\circ} \mathrm{C}$ and its activation energy was calculated as about 7,100 cal per mole.

The stability of APase I was tested. As

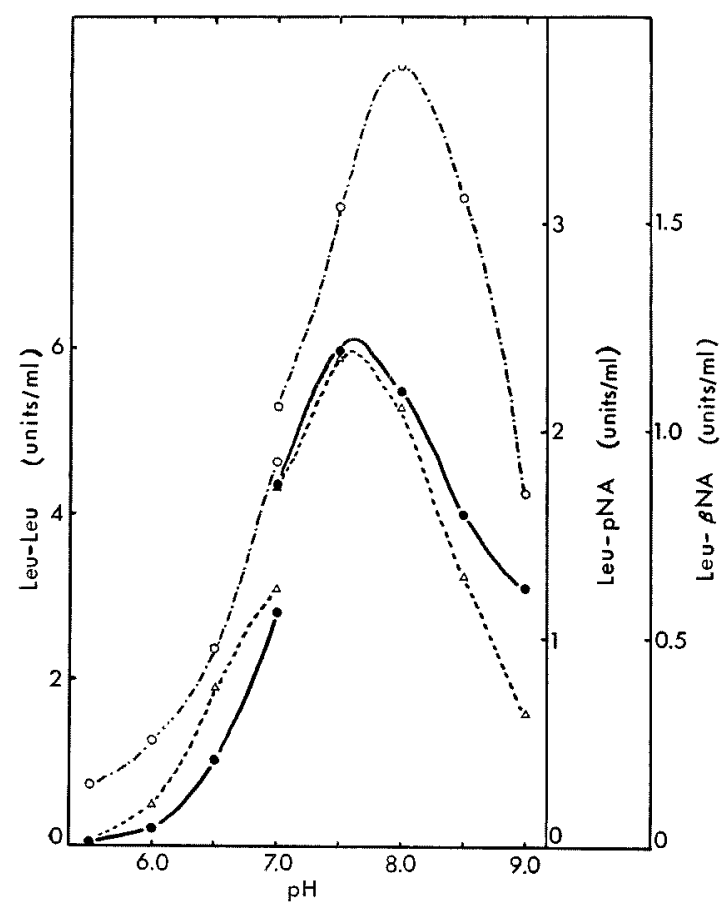

FIG. 5. Effect of pH on APase I Activity.

Enzyme activity was assayed against $1 \mathrm{~mm}$ of LeuLeu $(\triangle-\cdots), 1 \mathrm{~mm}$ of Leu- $p \mathrm{NA}(-\bullet)$ and $0.02 \%$ Leu- $\beta$ NA $(\mathrm{O}-\cdot \mathrm{O})$ in $50 \mathrm{~mm}$ of buffers at various $\mathrm{pH}$ values, as described in the text.

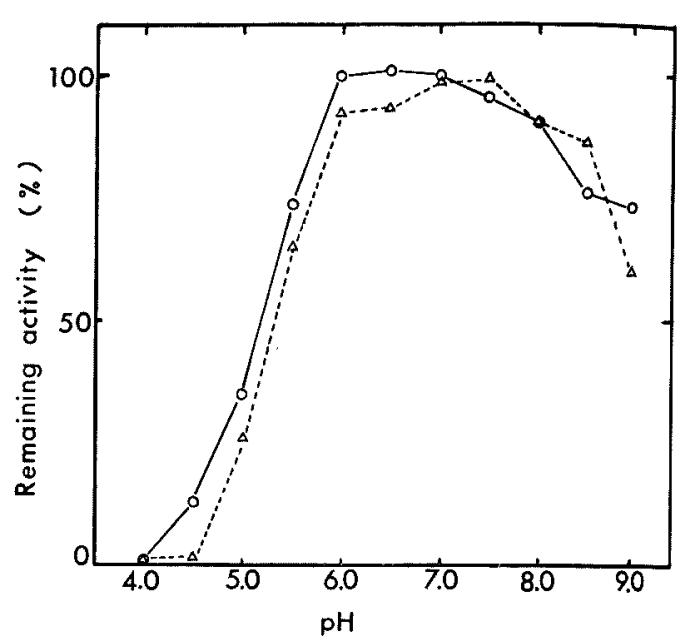

FIG. 6. pH Stability of APase I.

The enzyme $(3.5 \mu \mathrm{g})$ was incubated with $33 \mathrm{~mm}$ of buffer ( $\mathrm{pH} 4.0$ to 5.5, sodium acetate; $\mathrm{pH} 6.0$ to 7.0 , sodium phosphate; $\mathrm{pH} 7.5$ to 9.0 , Tris- $\mathrm{HCl}$ ) in a total volumne of $30 \mu \mathrm{l}$. The mixture was then incubated at $25^{\circ} \mathrm{C}$ for $12 \mathrm{hr}(\mathrm{O}-\mathrm{O})$ or at $37^{\circ} \mathrm{C}$ for $2 \mathrm{hr}(\triangle--\triangle)$. The remaining activity was assayed for $1 \mathrm{~mm}$ Leu- $p \mathrm{NA}$ in $0.1 \mathrm{~m}$ Tris- $\mathrm{HCl}$ buffer, $\mathrm{pH} 7.6$.

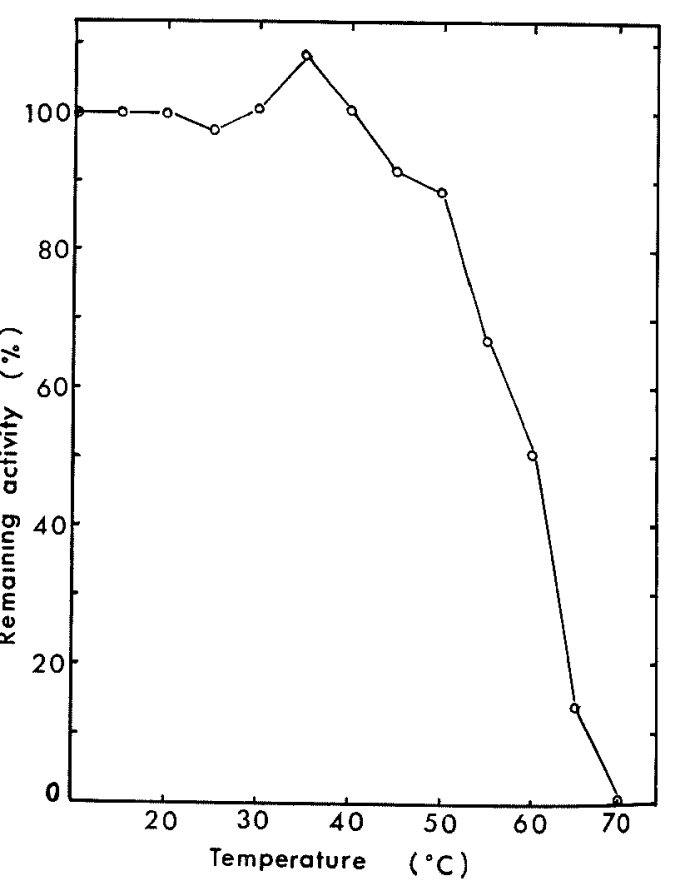

Fig. 7. Heat Stability of APase I.

The enzyme $(73 \mu \mathrm{g} / \mathrm{ml})$ in $50 \mathrm{~mm}$ Tris- $\mathrm{HCl}$ buffer, pH 7.6 was incubated at the indicated temperature for $30 \mathrm{~min}$. The remaining activity was measured for $1 \mathrm{mM} \mathrm{Leu-pNA}$ in the same buffer at $25^{\circ} \mathrm{C}$. 
seen from Figs. 6 and 7, the enzyme was most stable in the range of $\mathrm{pH} 6.0$ to 8.5 , and below $45^{\circ} \mathrm{C}$. Its activity was completely lost by incubation at $70^{\circ} \mathrm{C}$ for $30 \mathrm{~min}$.

\section{Effect of inhibitors}

The effects of various inhibitors on APase I are shown in Table II. The enzyme was inhibited by metal chelating agents, e.g. EDTA and $o$-phenanthroline. APase II was also

TABle II. EFfect of Various Reagents on APASE I.

After the enzyme and inhibitors had been incubated at $25^{\circ} \mathrm{C}$ for $30 \mathrm{~min}$, the remaining activity was measured for $1 \mathrm{~mm}$ Leu-pNA or $1 \mathrm{~mm}$ Leu-Phe in $50 \mathrm{~mm}$ Tris- $\mathrm{HCl}$ buffer, $\mathrm{pH} 7.6$.

\begin{tabular}{lcrr}
\hline \multirow{1}{*}{ Inhibitor } & $\begin{array}{c}\text { Concen- } \\
\text { tration }\end{array}$ & \multicolumn{2}{c}{$\begin{array}{c}\text { Remaining activity } \\
\text { for } \\
\text { Phe-Phe }\end{array}$} \\
& & $\%$ Leu- $p$ NA \\
\hline \multirow{3}{*}{ None } & $M$ & 100 & $\%$ \\
EDTA & & 100 \\
& $10^{-4}$ & 6 & 3 \\
o-Phenanthroline & $10^{-3}$ & 0 & 0 \\
& $10^{-4}$ & 42 & 33 \\
DFP & $10^{-3}$ & & 2 \\
& $10^{-4}$ & 105 & 102 \\
PCMB & $10^{-3}$ & 94 & 97 \\
$\beta$-Mercaptoethanol & $1.8 \times 10^{-4}$ & 17 & 15 \\
& $10^{-4}$ & 105 & 100 \\
L-Cysteine & $10^{-3}$ & 97 & 100 \\
& $10^{-4}$ & 100 & 101 \\
& $5 \times 10^{-4}$ & 53 & 57 \\
Monoiodoacetate & $10^{-3}$ & 0 & 2 \\
& $10^{-4}$ & 99 & 97 \\
& $10^{-3}$ & 27 & 29 \\
\hline
\end{tabular}

Table III. EFfect of Metal IONS ON the Inactivated APASE I Which Was Prepared With 1 mM EDTA, as Described IN the Text

The inactivated enzyme was incubated with $10 \mathrm{~mm}$ of metal ions at $25^{\circ} \mathrm{C}$ for $30 \mathrm{~min}$. Regenerated activity was determined against $1 \mathrm{~mm}$ of Leu-pNA in $50 \mathrm{~mm}$ Tris-HCl buffer, $\mathrm{pH} 7.6$.

\begin{tabular}{cc}
\hline Enzyme and its treatment & Activity \\
\hline & $\%$ \\
Native enzyme & 100 \\
Inactivated enzyme & 0 \\
$+\mathrm{ZnCl}_{2}$ & 68 \\
$+\mathrm{CoCl}_{2}$ & 12 \\
$+\mathrm{MnCl}_{2}$ & 8 \\
$+\mathrm{MgCl}_{2}$ & 1 \\
$+\mathrm{CaCl}_{2}$ & 0 \\
$+\mathrm{CdCl}_{2}$ & 0 \\
\hline
\end{tabular}

inhibited by these reagents. APase I was also inhibited by sulfhydryl reagents such as PCMB and monoiodoacetate. DFP had no effect on either of the enzymes.

\section{Effect of metal ions on the EDTA-treated APase I}

To determine the importance of metal ions on enzymic activity, APase I was inactivated by treatment with EDTA and reactivation by various metals was measured. The enzyme was treated with EDTA as follows; APase I was dialyzed against $10 \mathrm{~mm}$ of sodium phosphate buffer, $\mathrm{pH} 7.0$, containing $1 \mathrm{~mm}$ of EDTA for $5 \mathrm{hr}$, then the excess EDTA was removed by dialyzing the whole against water. In these experiments, the water used had been previously washed with chloroform containing $0.1 \%$ dithizone and had been distilled with all glass apparatus.

Reactivation was attempted by incubating the inactivated enzyme with various metal ions at $25^{\circ} \mathrm{C}$ for $30 \mathrm{~min}$. As shown in Table III, $\mathrm{ZnCl}_{2}$ was the most effective for reactivation. $\mathrm{CoCl}_{2}$ and $\mathrm{MnCl}_{2}$ were also shown to partially reactivate the inactivated enzyme.

\section{Substrate specificity}

The kinetic parameters of APase I for various dipeptides and amino acid amides are summarized in Table IV. The $V_{\max }$ values for all the dipeptides are similar except for Ala-Gly,

Table IV. Kinetic Constants for the Hydrolysis of Dipeptides and Amino ACID

Derivatives by APAse I.

\begin{tabular}{lcc}
\hline Substrate & $K m$ & Relative $V_{\text {max }^{a}}$ \\
\hline & mM & \\
Leu-Phe & 1.1 & 70 \\
Leu-Leu & 3.6 & 100 \\
Leu-Gly & 10.0 & 106 \\
Phe-Gly & 2.1 & 92 \\
Ala-Gly & 10.5 & 21 \\
Phe-Phe & 0.33 & 81 \\
Leu- $p$ NA & 3.1 & 39 \\
Leu- $\beta$ NA & 6.5 & 4 \\
Leu-NH & 12.5 & 79 \\
Phe-NH & 2.4 & 14 \\
\hline
\end{tabular}

a) $V_{\max }$ for Leu-Leu was taken as 100 . 
while the $K m$ values differ significantly from each other. As seen from the big changes in $\mathrm{Km}$ values for leucyl amino acids (Leu-Phe, Leu-Leu and Leu-Gly) and for amino acyl glycine (Leu-Gly, Phe-Gly, and Ala-Gly), both the $\mathrm{NH}_{2}$ - and $\mathrm{COOH}$-terminal residues of the dipeptides affected the enzyme-substrate interaction. Generally, bulky residues in both positions seem to be effective in the interaction and also in the hydrolysis.

Interestingly, no activity of APase I for IlePhe was detected in spite of its strong activity for Leu-Phe. Ile-Phe competitively inhibited the enzymatic hydrolysis of Leu- $p$ NA; the $K i$ value was $5.1 \mathrm{~mm}$. This shows that Ile-Phe can bind to the enzyme while it is not the substrate. Val-Gly also was not a substrate of APase I. These results suggest that the position of the branching on side chain of leucine exerts a marked influence on its susceptibility to enzymatic hydrolysis.

D-Phe-Leu was not a substrate of APase I, but did inhibit the hydrolysis of Leu- $p$ NA.

APase II hydrolyzed the dipeptides listed in Table IV including Ile-Phe at $\mathrm{pH} 7.6$, but did not hydrolyze Leu- $p$ NA, Leu- $\beta$ NA and Leu$\mathrm{NH}_{2}$. However, since the enzyme hydrolyzed Gly-Leu-Phe-Gly and Phe-Phe-OMe, it is not classified as a dipeptidase but as an amino-

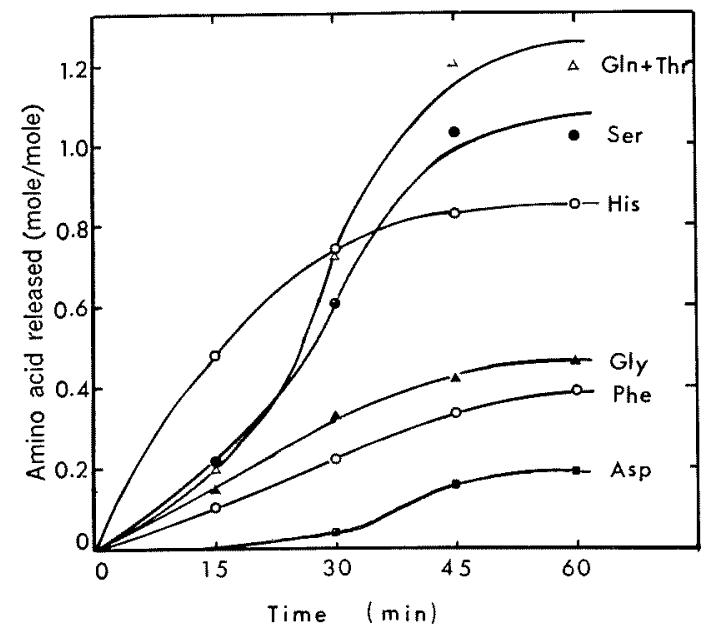

FIG. 8. Rate of the Release of Amino Acids from Glucagon (His-Ser-Gln-Gly-Thr-Phe-Thr-Ser-AspTyr-) during Digestion by APase I. peptidase, which requires a free $\mathrm{NH}_{2}$-group for the substrate.

\section{Hydrolysis of glucagon by APase I}

The enzyme hydrolyzed glucagon releasing only the amino acids, which were expected from the $\mathrm{NH}_{2}$-terminal sequence as shown in Fig. 8. This shows that the enzyme can be used to analyze the $\mathrm{NH}_{2}$-terminal sequences of peptides and proteins.

\section{DISCUSSION}

The APases described were found during the purification of CPase $\mathrm{Y}$, and were purified from the fractions adsorbed on DEAE-cellulose and DEAE-Sephadex A-50., ${ }^{2,5}$ Therefore, the aminopeptidase(s) which may be in the fraction eluted through an anion-exchanger were not mentioned here. As seen from Table I, APase I was not activated under the conditions used to activate CPase Y. This implies that the procedure is not necessary for the purification of APase I. However, the activation treatment of CPase $\mathrm{Y}$ was very helpful in removing the other proteins, as described earlier. ${ }^{2}$

APase I can hydrolyze both dipeptides and polypeptides (glucagon), and its molecular weight is about 200,000 . In contrast the polypeptidase described by Grassman et al ${ }^{6 \sim 8)}$ does not hydrolyze dipeptides, and the polypeptidase described by Johnson ${ }^{9}$ ' has a molecular weight of about 670,000. Therefore, APase I is not identical with the enzymes described by Grassman et al. and by Johnson. However, Johnson's enzyme and APase I are similar in their requirement of $\mathrm{Zn}$ for activity.

Matile et al. ${ }^{13)}$ has described four isozymes of aminopeptidase in yeast cells, all of which hydrolyzed Leu- $p$ NA or Leu- $\beta$ NA. One of them that was reported to be in the vacuoles is similar to our APase I with respect to the chromatographic behavior on Sephadex G-150.

APase I was inhibited by sulfhydryl reagents, i.e. PCMB and monoiodoacetate. This suggests that the sulfhydryl group in the enzyme is essential for activity. Cysteine also inhibited 
activity, probably due to its metal chelating ability. Since S-benzyl-cysteine-OMe and $\beta$ mercaptoethanol had no inhibitory effects on activity while cysteine-OMe inhibited activity, both the sulfhydryl and amino groups of cysteine seemed to be important in inhibition as metal chelators.

Acknowledgement. We express our sincere gratitute to Mr. I. Miyamoto for his help in the purification of the enzymes.

\section{REFERENCES}

1) T. Hata, R. Hayashi and E. Doi, Agr. Biol. Chem., 31, 150 (1967).

2) R. Hayashi, S. Moore and W. H. Stein, J. Biol. Chem., 248, 2296 (1973).

3) R. Hayashi, Y. Oka, E. Doi, and T. Hata, Agr. Biol. Chem., 32, 359 (1968).
4) R. Hayashi, Y. Oka and T. Hata, Agr. Biol. Chem., 33, 196 (1969).

5) R. Hayashi, T. Masuda, I. Miyamoto and T. Hata, in the Proceeding of the First International Congress of the International Association of Microbiological Societies, Tokyo, September $1 \sim 7$, 1974 (in press).

6) W. Grassmann and H. Dycherhoff, Z. physiol. Chem., 179, 41 (1928).

7) W. Grassmann, H. Dycherhoff and O. von Schoenebeck, Ber. Chem. Ges., 62, 1307 (1929).

8) W. Grassmann, L. Embden and H. Schneller, Biochem. Z., 271, 216 (1934).

9) M. J. Johnson, J. Biol. Chem., 237, 575 (1940).

10) T. Matoba and T. Hata, Agr. Biol. Chem., 36, 1423 (1972).

11) H. Wüst, "Methods of Enzymatic Analysis," ed. by H. Bergmayer, p. 824, 1963.

12) O. H. Lowry, N. J. Rosebrough, A. L. Farr and R. J. Randall, J. Biol. Chem., 193, 265 (1951).

13) P. H. Matile, A. Wiemken and W. Guyer, Planta (Berl.), 96, 43 (1971). 